\title{
Article \\ How Adding Chlorhexidine or Metallic Nanoparticles Affects the Antimicrobial Performance of Calcium Hydroxide Paste as an Intracanal Medication: An In Vitro Study
}

\author{
Kadiatou Sy ${ }^{1, *,+}$, Kevimy Agossa ${ }^{1,+}+\mathbb{D}$, Mickaël Maton ${ }^{1}$, Henry Chijcheapaza-Flores ${ }^{1} \mathbb{D}$, Bernard Martel ${ }^{2}$, \\ Florence Siepmann ${ }^{1}{ }^{\circledR}$, Etienne Deveaux ${ }^{1}$, Nicolas Blanchemain ${ }^{1}$ and Christel Neut ${ }^{3}(\mathbb{C}$ \\ 1 U1008-Controlled Drug Delivery Systems and Biomaterials, Inserm, CHU Lille, University of Lille, \\ 59000 Lille, France; kevimy.agossa@univ-lille.fr (K.A.); mickael.maton@univ-lille.fr (M.M.); \\ henry.chijcheapazaflores.etu@univ-lille.fr (H.C.-F.); florence.siepmann@univ-lille.fr (F.S.); \\ etienne.deveaux@univ-lille.fr (E.D.); nicolas.blanchemain@univ-lille.fr (N.B.) \\ 2 UMR 8207, UMET-Unité Matériaux et Transformations, CNRS-Centre National de la Recherche \\ Scientifique, INRA—Institut National de la Recherche Agronomique, ENSCL-Ecole Nationale Supérieure de \\ Chimie de Lille, University of Lille, 59655 Lille, France; bernard.martel@univ-lille.fr \\ 3 U1286 Infinite-Institute for Translational Research in Inflammation, Inserm, CHU Lille, University of Lille, \\ 59000 Lille, France; christelneut@nordnet.fr \\ * Correspondence: kadia2sy@gmail.com

Citation: Sy, K.; Agossa, K.; Maton, M.; Chijcheapaza-Flores, H.; Martel, B.; Siepmann, F.; Deveaux, E.; Blanchemain, N.; Neut, C. How Adding Chlorhexidine or Metallic Nanoparticles Affects the Antimicrobial Performance of Calcium Hydroxide Paste as an Intracanal Medication: An In Vitro Study. Antibiotics 2021, 10, 1352. https://doi.org/10.3390/ antibiotics 10111352

Academic Editors: Andreas Braun and Felix Krause

Received: 9 October 2021

Accepted: 2 November 2021

Published: 5 November 2021

Publisher's Note: MDPI stays neutral with regard to jurisdictional claims in published maps and institutional affiliations.

\begin{abstract}
The aim of our study was to explore the potential value of metallic ( $\mathrm{Ag}, \mathrm{Cu}$, and $\mathrm{Zn}$ ) salts, polymer/metallic nanoparticles, and chlorhexidine (CHX) for improving the antimicrobial activity of calcium hydroxide $(\mathrm{CH})$ against $E$. faecalis and $C$. albicans, associated with persistent endodontic infections. A first screening was performed by determining minimum inhibitory/bactericidal concentrations (MIC/MBC). Antimicrobial activity of the $\mathrm{CH}$ paste mixed with metallic salts, chitosan or cyclodextrin polymer metallic nanoparticles was compared to the antimicrobial activity of $\mathrm{CH}$ paste alone and $\mathrm{CH}+\mathrm{CHX}$ using a time-kill kinetics assay. The effect of the antimicrobials on the rheological and the key mechanical properties were also examined. Copper and zinc were discarded because of their MIC/MBC values and silver because of its kill time curve profile. Except for a slower setting time after $24 \mathrm{~h}$ and a higher weight loss after 1 week of incubation, the mechanical behavior of the $\mathrm{CH}$ paste was unaffected by the addition of $\mathrm{CHX}$. Polymeric/metallic nanoparticles failed to potentiate the antimicrobial effect of $\mathrm{CH}$. By contrast, $\mathrm{CHX}$ increased this effect and thus could help eradicate $E$. faecalis associated with persistent root canal infections without altering the desired key physical properties of the $\mathrm{CH}$ paste.
\end{abstract}

Keywords: endodontic infections; calcium hydroxide; chlorhexidine; copper; silver; zinc; nanoparticle; antimicrobial properties; mechanical properties; rheological properties

\section{Introduction}

Apical periodontitis is an inflammatory disorder of peri radicular tissues caused by persistent microbial infection within the root canal system [1]. The effective elimination of these microorganisms and the prevention of recontamination of the root canal system is the basis of root canal therapy [2]. Even when the most stringent procedures of chemomechanical cleaning and shaping are followed, in some cases, apical periodontitis may persist due to the anatomical complexities of the root canal system [2-4]. This is why the complementary application of intracanal antimicrobial medications between sessions has been proposed to significantly reduce the bacterial count [5-7].

Calcium hydroxide $(\mathrm{CH})$ paste is the most widely used intracanal medication [8,9]. Its antimicrobial effect has been attributed to the release of hydroxyl ions, which produce a highly alkaline environment ( $\mathrm{pH} 12.5$ ) in which most microorganisms cannot survive [10]. 
However, it has been suggested that the effectiveness of $\mathrm{CH}$ paste may be limited, especially in cases of persistent endodontic infections, due to the presence of resistant microbial species $[3,10]$. Enterococcus faecalis (E. faecalis), a facultative anaerobic Gram-positive bacterium, and Candida albicans (C. albicans), the most common yeast in the oral cavity, are the species most frequently associated with root canal treatment failure and refractory apical periodontitis [3]. They have been detected in $22-77 \%$ [3,7] to 1-17\% [11] of samples taken from infected root canals. They share characteristics such as dentin penetration ability and high $\mathrm{pH}$ tolerance, which may explain their resistance to $\mathrm{CH}$-based intracanal medications [3,10,11].

Various antimicrobial substances have been tested as adjuvants for $\mathrm{CH}$ paste in an attempt to increase its antimicrobial activity [12]. Chlorhexidine (CHX) is the reference antiseptic molecule in dentistry and displays a broad spectrum of activity against Gram-positive and Gram-negative bacteria as well as fungi [13-15]. It is biocompatible and adsorbs to dental tissues, allowing for prolonged, gradual release at therapeutic levels [13-16]. The benefit of mixing $\mathrm{CH}$ with $\mathrm{CHX}$ has been extensively studied $[13,15,17-19]$. Although a number of in vitro and clinical studies have reported that $\mathrm{CH}+\mathrm{CHX}$ is more effective in eliminating bacteria than $\mathrm{CH}$ alone $[13,15,18-20]$, other studies have failed to replicate this effect $[9,21-23]$. Differences in drug concentrations, solubility related to the form of the vehicle (aqueous, viscous, or oil), and antimicrobial testing methods may have contributed to this discrepancy $[11,13,16]$. Metallic nanoparticles (MNPs) have also proven to be effective in controlling oral infections when coated on or incorporated into various materials [24-26]. They have been proposed as promising alternatives to traditional antimicrobial agents [27-29]. Silver $(\mathrm{Ag})$, copper $(\mathrm{Cu})$, and zinc $(\mathrm{Zn}) \mathrm{MNPs}$ have received the most attention for their antimicrobial properties [24-27,30].

Polymeric nanoparticles (PNPs) have been recently developed as sophisticated carriers for drug delivery [31-34]. They are comprised of active pharmaceutical ingredients that are adsorbed to or entrapped in a polymeric structure [34]. The advantages of PNPs as drug carriers include their improved stability and drug release profiles and their biocompatibility, biodegradability, and ease of production [34]. Metallic nanoparticles have been successfully synthesized in aqueous solutions using chitosan (CHT) or cyclodextrin polymers (CDP) as reducing and stabilizing agents $[35,36]$. CHT is a biocompatible and biodegradable polysaccharide produced by the deacetylation of chitin extracted from crustaceans, yeasts, and algae [31]. CHT is biodegradable, biocompatible, hemostatic, antimicrobial, and analgesic [31]. These properties are related to its cationic character and the size of the polymer chain [37]. Cyclodextrins (CDs) are cyclic oligosaccharides with glucopyranose units joined by $\alpha-1,4$ glycosidic bonds. CDs have a truncated cone-shaped 3D structure. They have a hydrophobic cavity that can form inclusion complexes with a large variety of lipophilic molecules and that can work as a drug carrier in sustained release drug delivery systems [38-44]. Promising results have been reported with CHT/CDP/metallic nanoparticles. We recently developed a wound dressing with a protective cover composed of CHT and CDP for the sustained release of silver [33]. To date, no studies have investigated the addition of CHT or CDP metallic nanoparticles to $\mathrm{CH}$-based intracanal medications in order to enhance the antimicrobial activity of $\mathrm{CH}$ against $\mathrm{CH}$-resistant microorganisms.

The present study compared the in vitro antimicrobial activities of $\mathrm{CH}$ paste mixed with different metallic salts or polymer/metallic nanoparticles (PMNPs): CHT/CDP metallic nanoparticles $(\mathrm{Ag}, \mathrm{Cu}$, or $\mathrm{Zn})$. $\mathrm{CH}$ alone was used as a negative control, and $\mathrm{CH}+\mathrm{CHX}$ was used as a positive control. The aim was to determine the best intracanal medication candidate to help eradicate $E$. faecalis and $C$. albicans from infected root canals. Since ultimate clinical efficacy also depends on the ability of the material to be easily handled and spread into narrow anatomical spaces $[45,46]$, the key mechanical properties and flowability of the best candidate formulations were also investigated. 


\section{Results}

\subsection{Microbiological Tests}

2.1.1. Minimum Inhibitory Concentration (MICs) and Minimum Bactericidal Concentration (MBCs)

Table 1 shows the MICs results for all the antimicrobial agents tested on E. faecalis and C. albicans. The MICs/MBCs of copper $(>3200 \mathrm{mg} / \mathrm{L})$ and zinc $(\geq 3200 \mathrm{mg} / \mathrm{L})$ in free form or as PMNPs reached or exceeded $3200 \mathrm{mg} / \mathrm{L}$, the upper limit of the concentration range studied, meaning that the microbial strains studied were not susceptible to these molecules. This is why the copper- and zinc-based formulations were excluded from further experiments. The MICs ( 25 to $50 \mathrm{mg} / \mathrm{L}$ ) and MBCs (50 to $>100 \mathrm{mg} / \mathrm{L}$ ) of silver in free form or as PMNPs and the MICs/MBCs of chlorhexidine (2 to $16 \mathrm{mg} / \mathrm{L}$ ) indicated that these molecules were bactericidal and bacteriostatic at low concentrations and that the microbial strains studied were susceptible to them. Silver and CHX were thus selected for the next experiments.

Table 1. Minimal inhibitory concentrations (MICs) and minimal bactericidal concentrations (MBCs) $(\mathrm{mg} / \mathrm{L})$ of copper $\left(\mathrm{Cu}^{2+}\right)$, zinc $\left(\mathrm{Zn}^{2+}\right)$, silver $\left(\mathrm{Ag}^{+}\right)$, and chlorhexidine $(\mathrm{CHX})$ solutions, chitosan metallic nanoparticles (CHT/Cu, CHT/Zn, CHT/Ag), and cyclodextrin polymer metallic nanoparticles $(\mathrm{CDP} / \mathrm{Cu}, \mathrm{CDP} / \mathrm{Zn}, \mathrm{CDP} / \mathrm{Ag})$ against Enterococcus faecalis and Candida albicans $(n=3)$.

\begin{tabular}{ccc}
\hline Antimicrobials Agents & $\begin{array}{c}\text { Enterococcus faecalis } \\
\text { MIC/MBC }(\mathbf{m g} / \mathbf{L})\end{array}$ & $\begin{array}{c}\text { Candida albicans } \\
\text { MIC/MBC }(\mathbf{m g} / \mathrm{L})\end{array}$ \\
\hline $\mathrm{Cu}^{2+}$ & $>3200$ & $>3200$ \\
$\mathrm{CHT} / \mathrm{Cu}$ & $>3200$ & $>3200$ \\
$\mathrm{CDP} / \mathrm{Cu}$ & $>3200$ & $>3200$ \\
$\mathrm{Zn}$ & 3200 & 3200 \\
$\mathrm{CHT} / \mathrm{Zn}$ & $3200 />3200$ & $3200 />3200$ \\
$\mathrm{CDP} / \mathrm{Zn}$ & 3200 & 3200 \\
$\mathrm{Ag}^{+}$ & $50 />200$ & 50 \\
$\mathrm{CHT} / \mathrm{Ag}$ & $50 />100$ & $25 / 50$ \\
$\mathrm{CDP} / \mathrm{Ag}$ & $25 />100$ & $25 / 50$ \\
$\mathrm{CHX}$ & $2 / 16$ & 4 \\
\hline
\end{tabular}

\subsubsection{Time-Kill Kinetics Assay}

The time-kill curve profiles of the $\mathrm{CH}$ formulations with silver $\left(\mathrm{Ag}^{+}, \mathrm{CHT} / \mathrm{Ag}\right.$, $\mathrm{CDP} / \mathrm{Ag}$ ) and $\mathrm{CHX}$ against $C$. albicans and E. faecalis are presented in Figure 1. Silver was tested at concentrations ranging from $12.5 \mathrm{mg} / \mathrm{L}$ to $100 \mathrm{mg} / \mathrm{L}$ (Figure $1 \mathrm{a}-\mathrm{c}, \mathrm{e}-\mathrm{g}$ ), while $\mathrm{CHX}$ was tested using four different concentrations ranging from $0.5 \%\left(5 \times 10^{3} \mathrm{mg} / \mathrm{L}\right)$ to $4 \%\left(40 \times 10^{3} \mathrm{mg} / \mathrm{L}\right)$ (Figure $\left.1 \mathrm{~d}, \mathrm{~h}\right)$. Similar concentrations have been reported in the literature and correspond to $0.5 \times, 1 \times$, and $2 \times$ MIC for silver and $0.25 \times, 0.5 \times, 1 \times$, and $2 \times$ the most common concentration used in studies for $\operatorname{CHX}(2 \%)[7,24,30,31,47,48]$. The time-kill kinetics profile of the drug-free $\mathrm{CH}$ paste (dotted line) indicated that there was a reduction in viable $C$. albicans cells but not of $E$. faecalis cells. Silver-loaded $\mathrm{CH}$ pastes had similar time-kill kinetics profiles than $\mathrm{CH}$, for all forms $\left(\mathrm{Ag}^{+}, \mathrm{CHT} / \mathrm{Ag}\right.$, and $\left.\mathrm{CDP} / \mathrm{Ag}\right)$ and all concentrations. The time-kill kinetics profile of $\mathrm{CHX}$ against $\mathrm{C}$. albicans was similar to the control (drug-free $\mathrm{CH}$ paste). On the other hand, the time-kill kinetics profile of the $\mathrm{CHX}$-loaded $\mathrm{CH}$ paste against $E$. faecalis showed a reduction in the number of viable cells. The antimicrobial effect was dose-dependent. The difference was significant $(p<0.05)$ for the $1 \%$ and $2 \%$ CHX pastes and was highly significant $(p<0.01)$ for the $4 \%$ CHX paste compared to the control (drug-free $\mathrm{CH}$ paste). $\mathrm{CHX}$ at $1 \%$ and $2 \%$ displayed the best efficacy at the lowest concentrations against $E$. faecalis and C. albicans and were selected for the $\mathrm{CHX}$ release tests. 

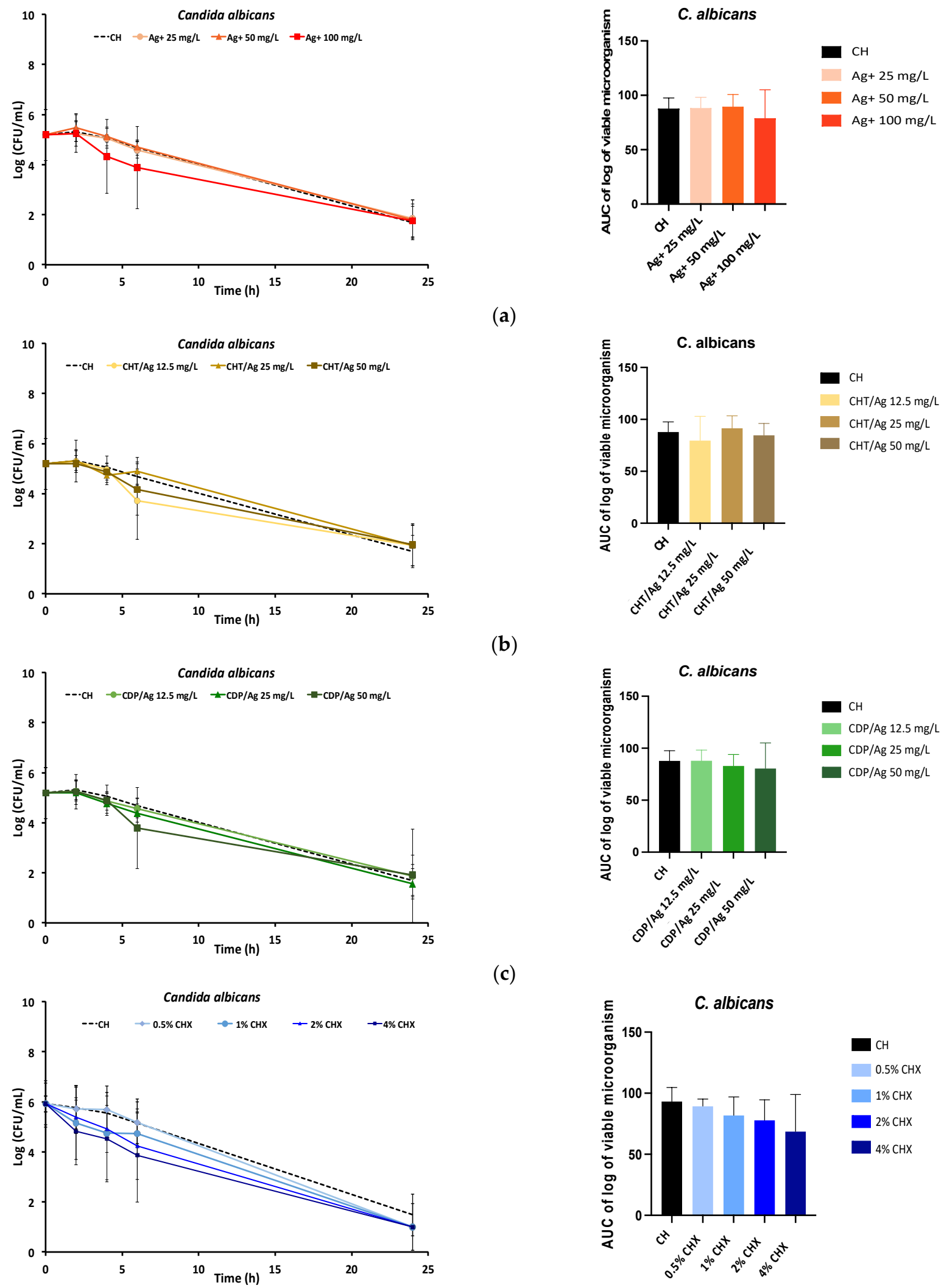

(d)

Figure 1. Cont. 

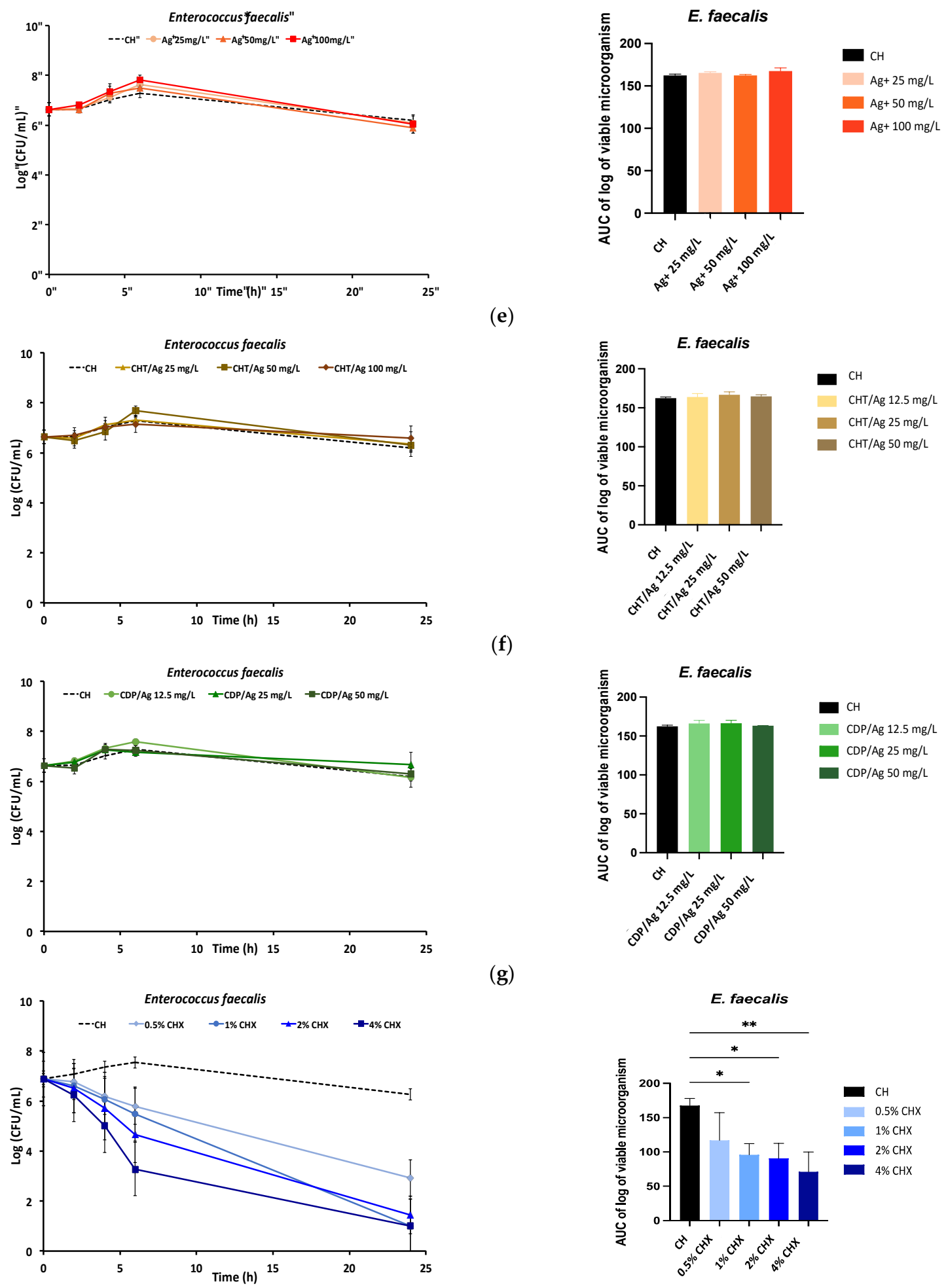

(h)

Figure 1. Time-kill kinetics curves and air under the curves (AUC) of the time-kill kinetics for Candida albicans (a-d) and Enterococcus faecalis $(\mathbf{e}-\mathbf{h})$ with calcium hydroxide $(\mathrm{CH})$ alone (dotted line) compared to the mixtures $(\mathbf{a}, \mathbf{e})$ : $\mathrm{CH}+$ silver solution (Ag+) $25 \mathrm{mg} / \mathrm{L}, 50 \mathrm{mg} / \mathrm{L}, 100 \mathrm{mg} / \mathrm{L} ;(\mathbf{b}, \mathbf{f}) \mathrm{CH}+$ silver as chitosan silver nanoparticles $(\mathrm{CHT} / \mathrm{Ag}) 12.5 \mathrm{mg} / \mathrm{L}$, $25 \mathrm{mg} / \mathrm{L}, 50 \mathrm{mg} / \mathrm{L}, 100 \mathrm{mg} / \mathrm{L}$; (c,g) CH + silver as cyclodextrin polymer silver nanoparticles (CDP/Ag) $12.5 \mathrm{mg} / \mathrm{L}, 25 \mathrm{mg} / \mathrm{L}$, $50 \mathrm{mg} / \mathrm{L}$, and $(\mathbf{d}, \mathbf{h}) \mathrm{CH}+\mathrm{CHX}$ solution $0.5 \%\left(5 \times 10^{3} \mathrm{mg} / \mathrm{L}\right), 1 \%\left(10 \times 10^{3} \mathrm{mg} / \mathrm{L}\right), 2 \%\left(20 \times 10^{3} \mathrm{mg} / \mathrm{L}\right), 4 \%\left(40 \times 10^{3} \mathrm{mg} / \mathrm{L}\right)$. $\left(^{*}\right)$ : significant difference $(p<0.05)$ and $\left.{ }^{* *}\right)$ : significant difference $(p<0.01)$ between the $\mathrm{CH}$ formulation and the test formulations (ANOVA test). 


\subsubsection{Drug Release Measurements}

Chlorhexidine and silver release were determined by HPLC-UV and ICP-MS, respectively, in order to assess the performance of a $\mathrm{CH}$ paste as a drug release system. Figure 2 shows the amount of $\mathrm{CHX}$ released $(\mathrm{mg} / \mathrm{L})$ as a function of time at four time points ( $4 \mathrm{~h}, 24 \mathrm{~h}, 28 \mathrm{~h}, 48 \mathrm{~h}$ ) for $1 \% \mathrm{CHX}$ and $2 \%$ CHX. These two dosages displayed comparable antimicrobial activities to $4 \%$ CHX (the highest dosage studied) and were thus selected given the risk of dose-dependent $\mathrm{CHX}$ toxicity [49]. The $1 \% \mathrm{CHX} / \mathrm{CH}$ paste released $2.350 \pm 0.008 \mathrm{mg} / \mathrm{L}$ of $\mathrm{CHX}$ after $4 \mathrm{~h}$, slightly less than the $\% \mathrm{CHX} / \mathrm{CH}$ paste $(2.630 \pm 0.011 \mathrm{mg} / \mathrm{L})(p<0.01)$, which represent release rates of $0.024 \%$ and $0.013 \%$ of the initial dosage, respectively. Comparable amounts of CHX were released at $24 \mathrm{~h}$ $(2.690 \pm 0.013 \mathrm{mg} / \mathrm{L}$ and $2.600 \pm 0.021 \mathrm{mg} / \mathrm{L}), 28 \mathrm{~h}(1.790 \pm 0.001 \mathrm{mg} / \mathrm{L}$ and $1.850 \pm 0.009$ $\mathrm{mg} / \mathrm{L})$, and $48 \mathrm{~h}(1.760 \pm 0.007 \mathrm{mg} / \mathrm{L}$ and $1.870 \pm 0.005 \mathrm{mg} / \mathrm{L})$ by the $1 \% \mathrm{CHX} / \mathrm{CH}$ and $2 \% \mathrm{CHX} / \mathrm{CH}$ pastes, respectively.

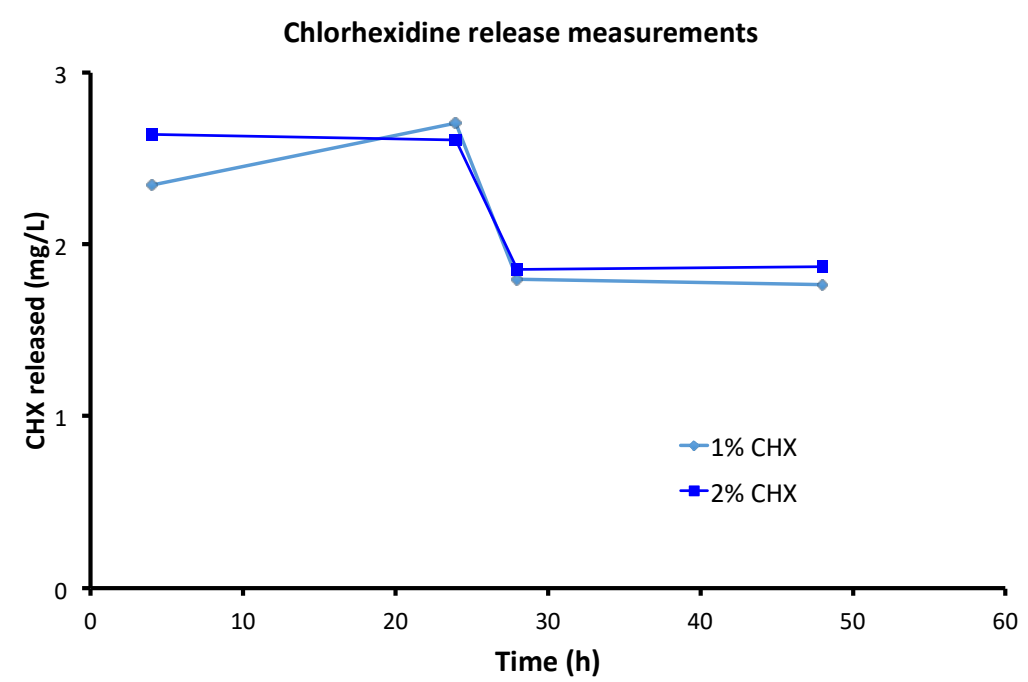

Figure 2. Chlorhexidine release measurements: release of chlorhexidine (CHX) from calcium hydroxide $+\mathrm{CHX}$ pastes with $1 \%\left(10 \times 10^{3} \mathrm{mg} / \mathrm{L}\right)$ and $2 \%\left(20 \times 10^{3} \mathrm{mg} / \mathrm{L}\right) \mathrm{CHX}$ over $48 \mathrm{~h}$.

As the time-kill assay indicated that there was no difference in antimicrobial activity between $\mathrm{CH}$ alone and $\mathrm{Ag}$-supplemented $\mathrm{CH}$ paste, we measured the amounts of silver released in the form of an Ag solution and a PMNP solution to explore a possible correlation between the release profile of the active ingredient and the antimicrobial effect observed. The values for silver after centrifugation as determined by ICP-MS were below the limit of quantification $(<0.1 \mu \mathrm{g} / \mathrm{L})$.

In terms of $\mathrm{CHX}$ release, $1 \% \mathrm{CHX}$ displayed the best efficacy at the lowest concentration and had a better release rate than $2 \%$ CHX $(0.024 \%$ vs. $0.013 \%$ at $4 \mathrm{~h})$ and was thus selected for the mechanical tests.

\subsection{Physical Properties}

Figure 3 shows the physical properties of $1 \%$ CHX.

\subsubsection{Injectability}

The results of the mechanical test in terms of the injectability of the $\mathrm{CH}$ paste with $1 \%$ $\mathrm{CHX}\left(10 \times 10^{3} \mathrm{mg} / \mathrm{L}\right)$ and the $\mathrm{CH}$ paste alone are given in Figure 3a. The two curves have similar profiles, indicating that there was no difference between the two formulations with respect to injectability. 


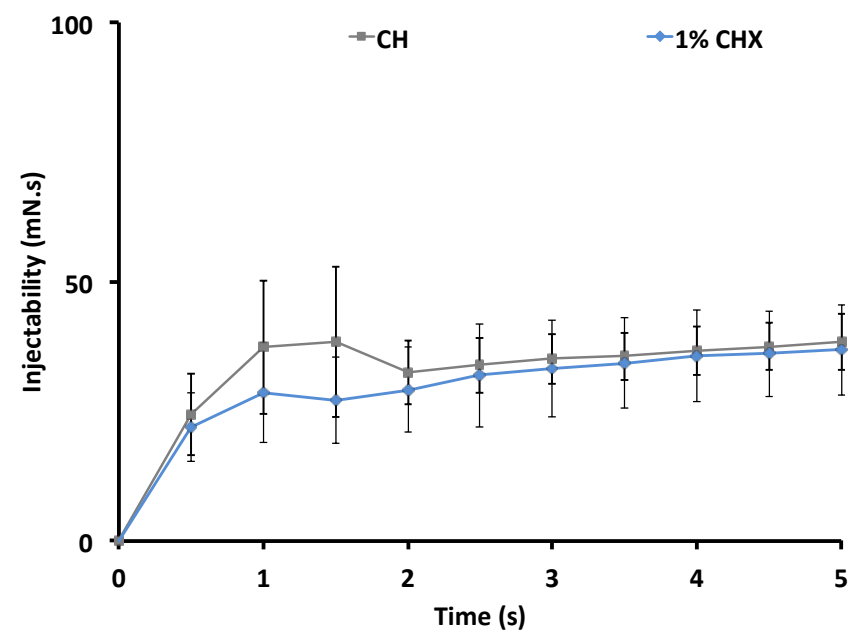

(a)

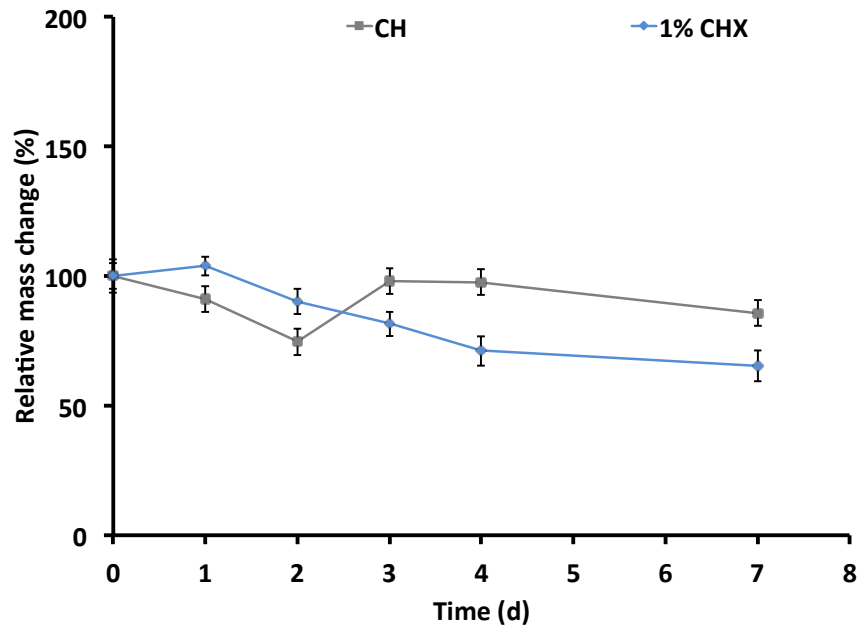

(b)

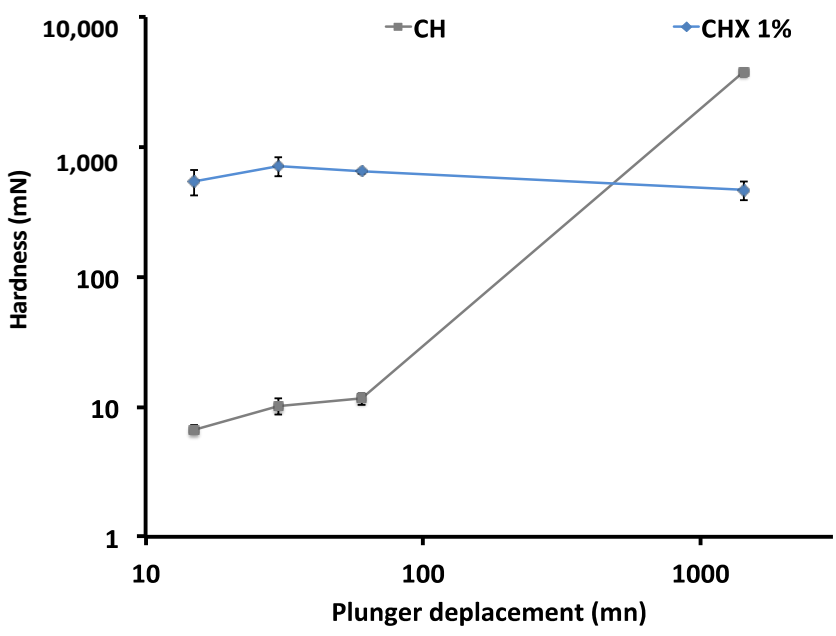

(c)

Figure 3. Physical properties of the chlorhexidine-free calcium hydroxide paste $(\mathrm{CH})$ and the calcium hydroxide paste containing $1 \%$ chlorhexidine (CHX) $\left(10 \times 10^{3} \mathrm{mg} / \mathrm{L}\right)$; (a) injectability; (b) effect of $\mathrm{CHX}$ on mass change; (c) setting kinetics. 


\subsubsection{Mass Change}

Figure $3 \mathrm{~b}$ shows the percentage of mass change for the different $\mathrm{CH}$ formulations: CHX-free $\mathrm{CH}$ paste $(\mathrm{CH})$ and $\mathrm{CH}+1 \% \mathrm{CHX}\left(10 \times 10^{3} \mathrm{mg} / \mathrm{L}\right)$ paste. Over a period of seven days, both formulations had mass losses ranging from $15 \%$ to $35 \%$. On day 7 , the mass loss of the CHX-CH paste was higher (35\%) than that of the CHX-free paste (15\%).

\subsubsection{Puncture Resistance Test}

Figure $3 \mathrm{c}$ shows the hardening curves. The initial hardness of the $\mathrm{CH}$ paste increased with the addition of CHX $(292 \pm 25.11 \mathrm{mN}$ vs. $5.29 \pm 0.23 \mathrm{mN})$. The hardness of the $\mathrm{CHX}$-free $\mathrm{CH}$ paste increased over time. At the end of the test, the hardness of the CHXfree formulation $(3767.74 \pm 265.86 \mathrm{mN})$ was higher than that of the CHX- supplemented formulation $(468.33 \pm 78.42 \mathrm{mN})$.

\subsection{Rheological Properties}

The rheological properties of the calcium hydroxide formulations are shown in Figure 4.

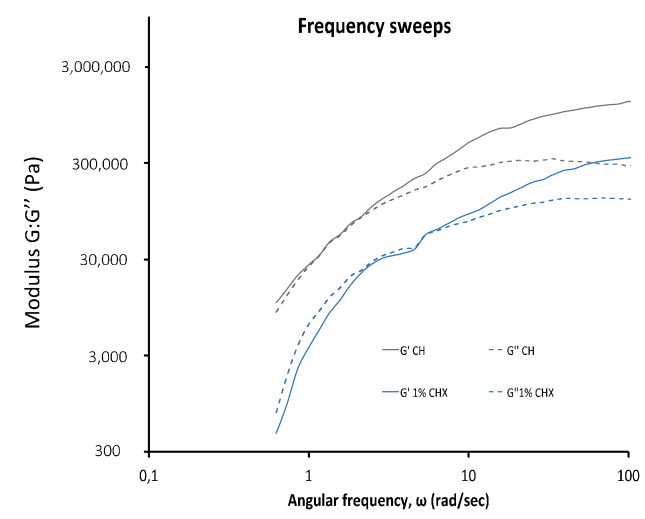

(a)

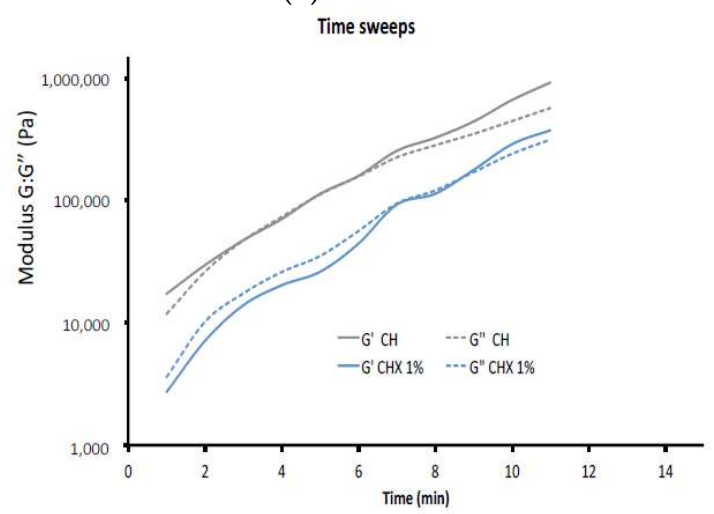

(c)

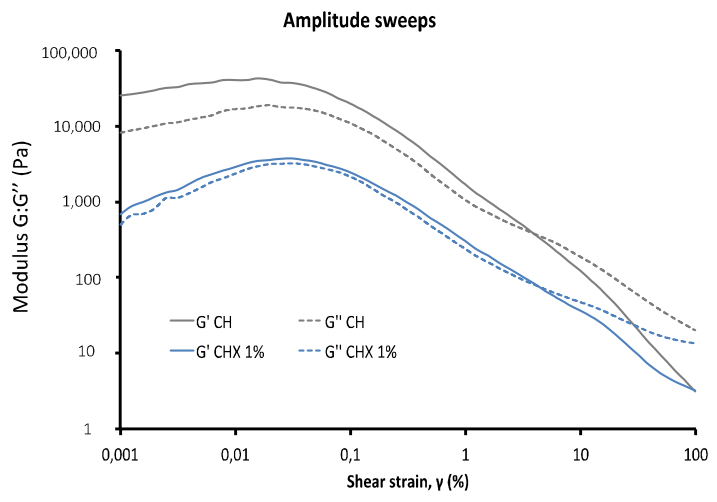

(b)

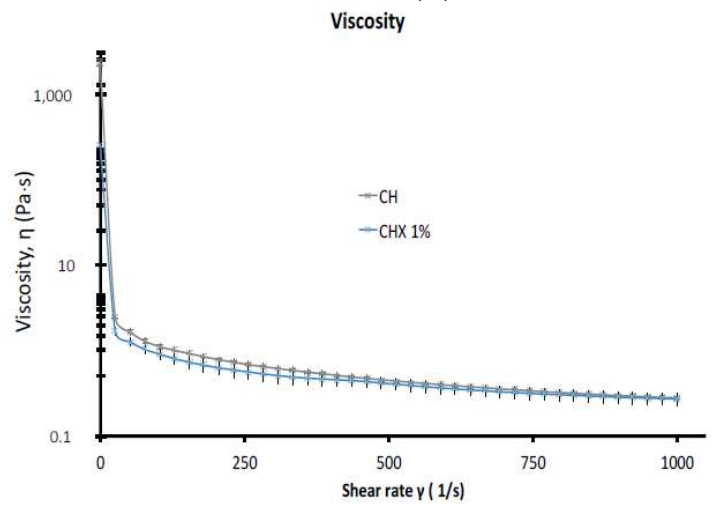

(d)

Figure 4. The rheological properties of the calcium hydroxide paste formulations: chlorhexidine-free calcium hydroxide paste $(\mathrm{CH})$ and calcium hydroxide with $1 \%$ chlorhexidine $(\mathrm{CHX})\left(10 \times 10^{3} \mathrm{mg} / \mathrm{L}\right)$ : (a) frequency sweeps: determining $\mathrm{G}^{\prime}$ and $\mathrm{G}^{\prime \prime}$ at a constant strain of $0.01 \%$; (b) amplitude sweeps: determining $\mathrm{G}^{\prime}$ and $\mathrm{G}^{\prime \prime}$ at a different shear strain; (c) time sweeps: evolution of the storage $\left(\mathrm{G}^{\prime}\right)$ and loss $\left(\mathrm{G}^{\prime \prime}\right)$ moduli as a function of time at a frequency of $2.5 \mathrm{rad} / \mathrm{s}$ at $20{ }^{\circ} \mathrm{C}$; (d) viscosity: shear-thinning evaluation by shear-rate dependent variations in viscosity.

The frequency sweep tests (Figure 4a) and the amplitude sweep tests (Figure 4b) were performed to determine the rheometric parameters. One preview test was performed for each sealer to analyze the setting pattern and to determine the rheometer settings (angular frequency of $2.5 \mathrm{rad} / \mathrm{s}$ ) using a strain amplitude of $0.01 \%$ and the data analysis method. 
For both formulations, $\mathrm{G}^{\prime}$ and $\mathrm{G}^{\prime \prime}$ increased over time. On the time sweep analysis curves (Figure $4 c)$, the storage moduli $\left(G^{\prime}\right)$ were very close to the loss moduli $\left(G^{\prime \prime}\right)\left(G^{\prime}=G^{\prime \prime}\right.$ approximately) for both formulations. For the CHX-free formulation, after $6 \mathrm{~min}, \mathrm{G}^{\prime}$ became higher than $G^{\prime \prime}$. In the presence of $1 \% \mathrm{CHX}$, the two moduli ( $G^{\prime}$ and $\left.G^{\prime \prime}\right)$ distanced themselves from each other: $G^{\prime \prime}$ was first higher than $G^{\prime}$ then, after 9 min, $G^{\prime \prime}$ became lower than $G^{\prime}$.

The amplitude sweeps showed that the moduli were lower with 1\% CHX than without CHX. For both formulations, the flow point was $0.06 \%$. The $\mathrm{G}$ points were $3.93 \%$ for the CHX-free formulation and $4.95 \%$ for the $1 \%$ CHX formulation. Figure $4 \mathrm{~d}$ shows the formulation viscosity during the first $15 \mathrm{~min}$. Both formulations displayed the same behavior but the CHX-free formulation was mechanically more consistent than the CHX formulation. Indeed, the initial viscosity was $2320 \mathrm{~Pa} \cdot \mathrm{s}$ for the $\mathrm{CH}$ paste alone and $253 \mathrm{~Pa} \cdot \mathrm{s}$ with the $\mathrm{CH}+\mathrm{CHX}$ paste, following which the values became similar for both formulations.

\section{Discussion}

The present study compared the in vitro antimicrobial activity of a $\mathrm{CH}$ paste mixed with different metallic salts $\left(\mathrm{Ag}_{2} \mathrm{SO}_{4}, \mathrm{CuSO}_{4}, \mathrm{ZnCl}_{2}\right)$ or $\mathrm{CHT} / \mathrm{CDP}$ metallic nanoparticles to $\mathrm{CH}$ alone as a negative control and the $\mathrm{CH}+\mathrm{CHX}$ paste as a positive control. The aim was to explore the potential value of metallic salts and CHT and CDP metallic nanoparticles as antimicrobial adjuvants for $\mathrm{CH}$ paste for eradicating E. faecalis and C. albicans, which are associated with root canal infections and are resistant to $\mathrm{CH}[3,10,11]$. According to our results, only $\mathrm{CHX}$ was an effective antimicrobial adjuvant for $\mathrm{CH}$ paste, reducing the number of E. faecalis colonies after 24-h incubation.

The dosages of $\mathrm{CHX}$ incorporated into the $\mathrm{CH}$ paste were selected according to the most commonly used concentrations in similar studies [13-15,18-20,22,25] for comparison purposes. For the metallic salts, in particular the PMNPs, which are still very little studied as intracanal medications, the antimicrobial susceptibilities of E. faecalis and C. albicans were first verified using a standard MIC/MBC determination method (CLSI M07-A8), and the dosages to be tested were selected based on the MICs $(0.5 \times, 1 \times$, and $2 \times)$, as previously described [50-52]. At this first screening stage, copper and zinc (whose MIC values reached or exceeded $3200 \mathrm{mg} / \mathrm{L}$ for both E. faecalis and C. albicans) were excluded. Conflicting results have been reported in the literature regarding the susceptibility of $C$. albicans and E. faecalis to zinc and copper. Aghatabay et al. and Martínez et al. reported MIC values for C. albicans reaching $12.5 \mathrm{mg} / \mathrm{L}$ for zinc and $129.7 \mathrm{mg} / \mathrm{L}$ for copper, respectively [53,54]. More recently, Meto et al. reported a similar C. albicans MIC for copper mixed with $\mathrm{CH}$ $(125 \mathrm{mg} / \mathrm{L})$ [55]. Nozari et al. reported that they did not observe any antimicrobial effect by zinc oxide on E. faecalis [56]. Conflicting results have also been reported with the same metals for other oral bacteria, including Streptococcus mutans [57]. It has been suggested that some metals may be inactivated by complex bacterial culture media [58] or that the discrepancies may be due to the different strains of the bacteria used in each study $[54,55]$. The MICs observed for silver salts and nanoparticles in the present study are generally consistent with those reported in previous studies [59-61].

As the results of the preliminary antimicrobial susceptibility test clearly indicated that the microorganisms studied are not susceptible to copper and zinc, only chlorhexidine and silver were selected to investigate their potential for enhancing the antimicrobial activity of the $\mathrm{CH}$ paste. A time-kill kinetics assay was used to monitor bacterial growth and death over a wide range of antimicrobial concentrations over time [62]. We used this technique rather than agar diffusion, which is the most commonly used technique to assess the antimicrobial activity of intracanal medications [63], given that the agar diffusion test has repeatedly been shown to be unreliable and unreproducible due to a number of limitations [64]. These limitations include reactions between agar ingredients and the antimicrobial agent, the lack of differentiation between bactericidal and bacteriostatic activity, variations related to the thickness of the agar gel, and the choice of cut-off size for the inhibition zones [64-66]. 
Three main conclusions can be drawn from our results with respect to the potential interest of antimicrobial-supplemented $\mathrm{CH}$ paste. First, our results suggested that the addition of silver in the form of a sulfate salt $\left(\mathrm{Ag}_{2} \mathrm{SO}_{4}\right), \mathrm{CHT} / \mathrm{Ag}$, or CDP/Ag does not improve the antimicrobial activity of $\mathrm{CH}$ against $E$ faecalis. A recent study has shown that the antibacterial efficacy of a silver nanoparticle (AgNP) $+\mathrm{CH}$ combination is superior to $\mathrm{CH}$ alone when using single bacteria species or biofilms [67] while another study failed to show this benefit [24]. These discrepancies are generally attributed to differences in methodology or to the characteristics of the nanoparticles used. Pratsinis et al. have shown that the antibacterial activity of AgNPs as well as their toxicity are size-dependent [68]. AgNPs that are less than $10 \mathrm{~nm}$ in size have enhanced antimicrobial activity and are more toxic. This has been attributed to a larger available surface area for interactions with microorganisms and a greater capacity to penetrate the bacteria [61,68-72]. Increasing evidence has also shown that AgNP activity may also depend on shape. It has been reported that triangular nanoparticles may be more effective than spherical and rod-like shapes. It has been suggested that a triangular shape gives a greater positive charge to the nanoparticles, which may, in turn, contribute to better antimicrobial activity [61]. In the present study, the fact that the CHT/Ag-and CDP/Ag-containing CH pastes had no antibacterial activity is most likely due to a lack of silver ion release into the medium. Indeed, the ICP-MS analysis showed that no Ag was detected in the bacterial culture medium after $24 \mathrm{~h}(<0.1 \mu \mathrm{g} / \mathrm{L})$. Polymer/silver or polymer $/ \mathrm{CH}$ interactions may explain this observation, but given the lack of studies on $\mathrm{CH}+$ PMNP mixtures as intracanal medications, further investigations are needed to elucidate this issue.

Second, our results indicated that the $\mathrm{CH}+\mathrm{CHX}$ combination is more effective in reducing the bacterial count of E. faecalis than $\mathrm{CH}$ paste alone and that this effect is dosedependent, which is consistent with the known properties of CHX as an antibacterial agent [13]. A large number of recent studies have reported similar results [13,15,18-20,30], but the benefit of mixing $\mathrm{CH}$ with $\mathrm{CHX}$ to improve the antibacterial activity of $\mathrm{CH}$ remains controversial. A systematic review and meta-analysis by Saatchi et al., which included nine studies, failed to show a significant difference between $\mathrm{CH}+\mathrm{CHX}$ and $\mathrm{CH}$ alone in their effects on E. faecalis [63]. However, it should be mentioned that the most recent studies (published after 2012) were not included in this systematic review and that the comparisons made in the meta-analysis were very heterogeneous.

Lastly, we observed the same patterns of reduction of microbial counts between $1 \mathrm{~h}$ and $24 \mathrm{~h}$ of incubation of $\mathrm{C}$. albicans in the presence of $\mathrm{CH}$ alone or in combination with the different antimicrobials. This means that the $\mathrm{CH}$ paste alone or combined with any of the antimicrobials studied has comparable fungicidal activity against $C$. albicans. This result contradicts the resistance of $\mathrm{C}$. albicans to $\mathrm{CH}$ that is commonly documented in the literature $[3,55,73]$. Waltimo et al. studied the susceptibility of common oral Candida species to a saturated aqueous $\mathrm{CH}$ solution and reported that the sensitivity to $\mathrm{CH}$ was variable. Only 6 of 16 strains survived after $3 \mathrm{~h}$ but were killed after $6 \mathrm{~h}$ of incubation [73]. Similar results were reported by Weckwerth et al., who studied the susceptibility of 30 strains of oral C. albicans isolated from clinical specimens [74]. A decline in Candida growth was observed at 6, 12, and $24 \mathrm{~h}$, with full inhibition of growth after $48 \mathrm{~h}$ of direct contact with an aqueous $\mathrm{CH}$ solution [74]. However, it seems evident that the resistance of C. albicans to $\mathrm{CH}$ in vivo is higher because the microorganisms are able to invade dentinal tubules and remain protected from the action of alkaline endodontic medications because of the buffering effect of dentin $[66,75,76]$.

The key characteristics of an ideal endodontic filling material remain as stated by Grossman in [77]. In particular, from a physical and mechanical point of view, the filling material is expected to (i) be easy to handle, (ii) have an ample working time, (iii) be adaptable to the complex internal anatomy of root canals, and (iv) be dimensionally stable and insoluble in tissue fluid. It should be noted that this last point does not apply in the same way to temporary filling materials such as $\mathrm{CH}$-based medications, which must be completely removed from the canal before the final obturation as the presence of $\mathrm{CH}$ 
paste remnants may negatively affect the quality of the root canal filling and reduce dentin bond strength and sealer adaptation [78]. The flowability of the filling material is clinically important because it improves the penetration of the sealer into the complex root canal, thus contributing to the clinical performance of the material [79-81]. This parameter can be precisely studied using a strain-controlled rheometer that provides information on the rheological properties of root canal sealers as a function of time and temperature [79]. Relatively few studies have investigated the rheological properties of root canal sealers $[82,83]$ and, to our knowledge, none have investigated $\mathrm{CH}$-based temporary medications. Injectability and penetration resistance tests are also standard methods for evaluating the ease of handling of injectable materials and the setting time [62,84]. Monitoring mass changes in water also provides information on water uptake/loss, which contributes to the swelling and/or disintegration of the material $[62,84]$. This is why we used the above methods to characterize the key physical properties of the $\mathrm{CH}+1 \% \mathrm{CHX}$ mixture. This formulation displayed the best efficacy at the lowest drug concentration. A slight rheofluidifying effect of $\mathrm{CH}+\mathrm{CHX}\left(\mathrm{G}^{\prime \prime}>\mathrm{G}^{\prime}\right)$ at 9 min vs. 6 min for $\mathrm{CH}$ alone was observed but, overall, the rheological properties and ease of handling of the $\mathrm{CH}$ paste were not altered by the addition of CHX, as shown by the similar viscosity and injectability curves for the two formulations. Moreover, the addition of $1 \% \mathrm{CHX}$ seemed to slow down the setting of the $\mathrm{CH}$ paste and promote mass loss over time. The $\mathrm{CH}+\mathrm{CHX}$ mixture had lower penetration resistance at $24 \mathrm{~h}$ and a higher mass loss after 7 days. The hydrophilic nature of $\mathrm{CHX}$ may explain these differences as it would promote the hydration of the $\mathrm{CH}$ paste, which would delay its hardening. In practice, the faster mass loss of the $\mathrm{CH}+\mathrm{CHX}$ mixture could reflect faster resorption of the material in vivo due to its solubilization by tissue fluids.

The limitations of the present study are evidently related to the in vitro models used, which only made it possible to approximate a few of the parameters that could be involved in vivo. Notably, antimicrobial activity was evaluated with planktonic bacteria. In vivo, endodontic pathogens are organized in the form of polymicrobial biofilms whose susceptibility to antimicrobial agents can be very different. Further studies are required to confirm these results and correlate them with clinical outcomes.

\section{Materials and Methods}

\subsection{Media, Molecules, and Formulations}

\subsubsection{Cultures and Media}

Different types of tests, which are described in detail below, were performed using either a collection strain (C. albicans ATCC10231) or a strain isolated from a patient with a periapical lesion (E. faecalis C159.6). These strains were obtained from the Laboratory of Bacteriology collection at the College of Pharmacy, University of Lille, France. The two strains were subcultured in Mueller-Hinton broth (MHB composed of MH culture medium and ultra-pure water), seeded on Mueller Hinton agar (MHA composed of Mueller-Hinton culture medium (Oxoid ${ }^{\circledR}$, Basingstoke, UK) and 1.5\% agar (Becton-Dickinson ${ }^{\circledR}$, Le Pont de Claix, France)) diluted in cysteinated Ringer (RC) solution (Merck ${ }^{\circledR}$, Darmstadt, Germany).

\subsubsection{Preparation of Antimicrobial Agents}

The antimicrobials were tested in the form of solutions: chlorhexidine digluconate (Evonik, Hanau, Germany), silver sulfate $\left(\mathrm{Ag}_{2} \mathrm{SO}_{4}\right)$ (Sigma-Aldrich ${ }^{\circledR}$, Saint-Quentin Fallavier, France), copper (II) sulfate anhydrous $\left(\mathrm{CuSO}_{4}\right)$ (Alfa Aesar ${ }^{\circledR}$, Kandel, Germany), and zinc chloride anhydrous $\left(\mathrm{ZnCl}_{2}\right)$ (Alfa Aesar $\left.{ }^{\circledR}\right)$. Metallic ions (silver (Ag), copper $(\mathrm{Cu})$, and zinc $(\mathrm{Zn})$ were also tested in the form of PMNPs and were formulated with (i) low molecular weight chitosan (CHT) (MW: $140 \mathrm{~kg} \mathrm{~mol}^{-1}$; DD: 77\%) (Sigma-Aldrich ${ }^{\circledR}$ ) to produce chitosan/metallic nanoparticles (CHT/MNPs) and were named, respectively, $\mathrm{CHT} / \mathrm{Ag}, \mathrm{CHT} / \mathrm{Cu}$, and CHT/Zn or (ii) with cyclodextrin polymer (Kleptose ${ }^{\circledR}$, Roquette, Lestrem, France) to produce cyclodextrin polymer/metallic nanoparticles (CDP/MNPs) named, respectively, $\mathrm{CDP} / \mathrm{Ag}, \mathrm{CDP} / \mathrm{Cu}$, and $\mathrm{CDP} / \mathrm{Zn}$, as previously described $[33,36]$. 
An aqueous CHX solution was prepared by diluting $1024 \mathrm{mg}$ of lyophilized digluconate $\mathrm{CHX}$ powder in $100 \mathrm{~mL}$ of distilled water. The metallic solutions $\left(\mathrm{Ag}^{+}, \mathrm{Cu}^{2+}, \mathrm{Zn}^{2+}\right)$ were prepared by diluting $640 \mathrm{mg}$ of $\mathrm{Ag}_{2} \mathrm{SO}_{4}, \mathrm{CuSO}_{4}$, or $\mathrm{ZnCl}_{2}$ in $100 \mathrm{~mL}$ of ultra-pure water.

The aqueous $\mathrm{CHT} / \mathrm{Ag}, \mathrm{CHT} / \mathrm{Cu}, \mathrm{CHT} / \mathrm{Zn}$ nanoparticle solutions ( $0.5 \%$ chitosan) were prepared in an acid medium (1\% v/v lactic acid). The $\mathrm{Ag}_{2} \mathrm{SO}_{4}, \mathrm{CuSO}_{4}$, and $\mathrm{ZnCl}_{2}$ solutions $(6400 \mathrm{mg} / \mathrm{L})$ were prepared in volumetric flasks containing $100 \mathrm{~mL}$ of a $1 \%(v / v)$ aqueous lactic acid $\left(\mathrm{VWR}^{\circledR}\right.$, Fontenay Sous Bois, France) solution in ultra-pure water. The appropriate amount $(500 \mathrm{mg}$ ) of chitosan was then mixed with the lactic acid solution and was stirred for $24 \mathrm{~h}$. Once the chitosan solution became transparent, $640 \mathrm{mg}$ of $\mathrm{Ag}_{2} \mathrm{SO}_{4}$, $\mathrm{CuSO}_{4}$, or $\mathrm{ZnCl}_{2}$ was added to the volumetric flask to obtain $100 \mathrm{~mL}$ of each CHT/MNP solution. A similar procedure was used for the production of aqueous $\mathrm{CDP} / \mathrm{Ag}, \mathrm{CDP} / \mathrm{Cu}$, and CDP/Zn nanoparticle solutions containing $0.3 \%$ cyclodextrin polymer with $6400 \mathrm{mg} / \mathrm{L}$ of $\mathrm{Ag}_{2} \mathrm{SO}_{4}, \mathrm{CuSO}_{4}$, or $\mathrm{ZnCl}_{2}$. These solutions were prepared in 100-mL volumetric flasks. The appropriate amount $(300 \mathrm{mg})$ of cyclodextrin polymer was mixed in ultra-pure water and was stirred overnight (50 rpm). Next, $640 \mathrm{mg}$ of $\mathrm{Ag}_{2} \mathrm{SO}_{4}, \mathrm{CuSO}_{4}$, or $\mathrm{ZnCl}_{2}$ was added to the volumetric flasks to produce $100-\mathrm{mL}$ solutions of CDP/MNPs. The CHT/MNP and $\mathrm{CDP} / \mathrm{MNP}$ solutions were stirred for $24 \mathrm{~h}$ at $70{ }^{\circ} \mathrm{C}$ in the dark.

\subsubsection{Formulation of the Calcium Hydroxide Pastes}

$\mathrm{CH}$ paste was prepared by mixing calcium hydroxide powder (Hidroxido de calcio; DentaFlux, Madrid, Spain) and distilled water $(1: 1 ; w / v)$ and spatulating the mixture on a glass plate. Antimicrobial-free $\mathrm{CH}$ paste was used as a negative control. The test formulations were produced by replacing the distilled water with the antimicrobial solutions described above (CHX, $\mathrm{Ag}^{+}, \mathrm{Cu}^{2+}, \mathrm{Zn}^{2+}, \mathrm{CHT} / \mathrm{Ag}, \mathrm{CHT} / \mathrm{Cu}, \mathrm{CHT} / \mathrm{Zn}, \mathrm{CDP} / \mathrm{Ag} \mathrm{CDP} / \mathrm{Cu}$, or $\mathrm{CDP} / \mathrm{Zn})$.

\subsection{Antimicrobial Properties}

\subsubsection{Minimal Inhibitory Concentrations and Minimal Bactericidal Concentrations}

The MICs and MBCs were determined using Clinical and Laboratory Standards Institute protocols (CLSI M07-A9, CLSI M26-A) [85]. Briefly, the broth microdilution method was used with ten concentrations of the antimicrobials (chlorhexidine digluconate solution, and silver, copper, and zinc solutions or in the form of PMNPs) [86]. The MICs and MBCs of C. albicans and E. faecalis were determined in triplicate, with antimicrobial concentrations ranging from 1 to $3200 \mathrm{mg} / \mathrm{L}$, depending on the antimicrobial agent. A start inoculum of $10^{6}$ cells $/ \mathrm{mL}$ was used. The MICs were the lowest concentrations of the antimicrobials with which no visible growth occurred. The CFUs were visible after a 24- to 48 -h incubation at $37^{\circ} \mathrm{C}$ under aerobic conditions. The MBCs were the lowest concentrations at which no colony formation occurred. The first selection of antimicrobials was made based on the MIC and MBC results. The antimicrobials with the lowest MICs and MBCs were selected for the next step.

\subsubsection{Time-Kill Kinetics Assay}

A time-kill kinetics assay was performed to determine the time-dependent reduction in E. faecalis and C. albicans (Colony Forming Units [CFUs]) caused by the antimicrobials, as previously reported [62]. Briefly, bacterial suspensions were exposed to the antimicrobials for different periods of time, and the CFUs of the surviving microbial populations were counted. Each formulation (1 mL) was placed in a 15-mL Falcon tube (Greiner, Courtaboeuf, France). Fresh MH medium was added $(8 \mathrm{~mL})$ followed by $1 \mathrm{~mL}$ of $E$. faecalis or C. albicans suspension $\left(10^{4}-10^{6}\right.$ bacteria $\left./ \mathrm{mL}\right)$. The tubes were then incubated for $24 \mathrm{~h}$ at $37^{\circ} \mathrm{C}$. At 0 , 2, 4, 6 and $24 \mathrm{~h}, 100-\mu \mathrm{L}$ samples were removed from the tubes and were diluted 10-fold with RC. The dilutions $(100 \mu \mathrm{L})$ were plated on MHA plates, which were incubated for $24 \mathrm{~h}$ at $37^{\circ} \mathrm{C}$. The numbers of colonies were counted, and the results are expressed as log 
$\mathrm{CFU} / \mathrm{mL}$. All experiments were performed in triplicate, and the results are expressed as means \pm standard deviations.

\subsubsection{Drug Release Measurements}

The antimicrobials $(100 \mu \mathrm{L})$ were placed in the bottom of 2-mL Eppendorf ${ }^{\circledR}$ vials using a standard syringe. The vials were horizontally shaken at $37^{\circ} \mathrm{C}$ and $80 \mathrm{rpm}$ (GFL 3033; Gesellschaft fuer Labortechnik, Burgwedel, Germany). At selected time points, the release medium (deionized water) was completely renewed. The amounts of drugs in the bulk fluids that were withdrawn from the vials were determined by HPLC-UV (Waters Alliance 2695 separation module, Waters $2489 \mathrm{UV} /$ vis detector), as previously described [87]. Briefly, 20- $\mu \mathrm{L}$ samples were injected onto a C18 RP column (Gemini $5 \mu \mathrm{m} \mathrm{C18} 110 \AA$, $100 \mathrm{~mm} \AA \sim 4.6 \mathrm{~mm}$; Phenomenex, Le Pecq, France). The flow rate was $1.5 \mathrm{~mL} / \mathrm{min}$. The column was kept at room temperature, and the detection wavelength was set at $\lambda=239 \mathrm{~nm}$. All experiments were performed in triplicate, and the results are expressed as means \pm standard deviations.

\subsection{Physical Properties}

Depending on the results of the antimicrobial test, the antimicrobial agents displaying the best antibacterial properties were tested mechanically.

\subsubsection{Injectability}

The injectability of the different $\mathrm{CH}$ paste formulations was measured using a texture analyzer in compression mode (speed: $1 \mathrm{~mm} / \mathrm{s}$ ), as previously described [88]. The work required to expel the $\mathrm{CH}$ paste was calculated. Briefly, a cylindrical probe $(6 \mathrm{~mm}$ in diameter) of the texture analyzer was used to drive the piston 10-mm downward (load cell: 50 kg, TA.XT.Plus; Stable Micro Systems, Surrey, UK). Force-distance profiles were recorded, and the work required to expel the liquid formulation from the syringe was calculated. For comparison purposes, the injectability of pure water was also determined. All the experiments were performed in triplicate, and the results are expressed as means \pm standard deviations.

\subsubsection{Monitoring Changes in Dynamic Mass}

The mass change \% at time $t$ was calculated, as previously described [87], using the following equation:

$$
\text { mass change }(\%)(t)=100 \cdot \frac{\operatorname{mass}(t)-\operatorname{mass}(t=0)}{\operatorname{mass}(t=0)},
$$

where the mass $(t=0)$ is the initial weight of the $\mathrm{CH}$ paste formulation used. The experiments were performed in triplicate, and the results are expressed as means \pm standard deviations.

\subsubsection{Penetration Resistance Test}

The setting profiles of the $\mathrm{CH}$ paste samples were determined by measuring their penetration resistance at different times (15 min, $30 \mathrm{~min}, 60 \mathrm{~min}, 24 \mathrm{~h}$ ) using an adaptation of a previously published protocol [84]. Briefly, a cylindrical hole was cut in the center of an agar gel and was filled with $200 \mu \mathrm{L}$ of $\mathrm{CH}$ paste. A texture analyzer (TA.XT.Plus, load125cell: $1 \mathrm{~kg}$ ) in compression mode and a spherical probe $(6 \mathrm{~mm})$ were used for the puncture test. Once in contact with the $\mathrm{CH}$ paste sample, the probe was lowered downward at a constant speed $(1 \mathrm{~mm} / \mathrm{s})$ and was stopped when its penetration depth was equal to the target distance $(5 \mathrm{~mm})$. The force-displacement profile was recorded, and the area under the force-time plot was calculated. The tests were performed in triplicate at room temperature. 


\subsection{Rheological Properties}

The rheological properties were evaluated using a strain-controlled modular compact rheometer (MCR 301 Physica: Anton Paar, Les Ulis, France) with a parallel plate geometry (diameter of $25 \mathrm{~mm}$ ) and a Peltier plate temperature device (HPTD200, Anton Paar) to control the temperature [89]. A 1-mm gap was used for all the measurements. The $\mathrm{CH}$ paste samples were placed on the lower plate of the rheometer immediately after mixing. The upper plate was placed in the measuring position, and excess sample was trimmed using a spatula. The storage $\left(\mathrm{G}^{\prime}\right)$ and loss $\left(\mathrm{G}^{\prime \prime}\right)$ moduli of the paste samples were evaluated as a function of time at $20^{\circ} \mathrm{C}$ in the oscillatory mode at a frequency of $2.5 \mathrm{rad} / \mathrm{s}$, a $0.01 \%$ strain, and a constant speed of $300 \mathrm{~s}^{-1}$. The measurements began $90 \mathrm{~s}$ after the initial mixing in order to standardize the measurements. The tests were performed in triplicate for each group.

\subsection{Statistical Analysis}

The values were tabulated using Microsoft Office Excel Mac OS 2011 (14.4.7 [141117] version). The significance level of the statistical analysis was set at $p<0.05$. The time-kill assay test results were analyzed by ANOVA followed by a Tukey Kramer test. All the experiments were repeated independently at least three times.

\section{Conclusions}

Within the limits of the present study, we can conclude that a mixture of $\mathrm{CH}$ and $\mathrm{CHX}$ as an intracanal medication could help eradicate E. faecalis associated with secondary and persistent root canal infections without altering the desired key physical properties of the $\mathrm{CH}$ paste. Our results do not support the use of CHT or CDP metallic nanoparticles as antimicrobial adjuvants for $\mathrm{CH}$-based medication. Further studies are needed to optimize the antimicrobial activity of CHT/CDP metallic nanoparticles before they can be used as an adjuvant for endodontic therapy.

Author Contributions: Conceptualization, K.S., K.A., E.D., N.B. and C.N.; methodology, K.S. and K.A.; validation, C.N., N.B., E.D. and F.S.; formal analysis, K.S., M.M. and H.C.-F.; investigation, K.S. and K.A.; resources, F.S., B.M., N.B. and C.N.; data curation, K.S. and K.A.; writing-original draft preparation, K.S. and K.A.; writing-review and editing, N.B., C.N. and E.D. All authors have read and agreed to the published version of the manuscript.

Funding: This research has received no external funding.

Data Availability Statement: The data presented in this study are available on request from the corresponding author.

Acknowledgments: The authors would like to warmly thank Isabelle Houcke and Séverine Mahieux, Institute for Translational Research in Inflammation, Jéremy Verin, Controlled Drug Delivery Systems and Biomaterials and Nicolas Beauval, Laboratoire de Toxicologie et Génopathies for their amazing work and their precious help.

Conflicts of Interest: The authors declare no conflict of interest.

\section{References}

1. Siqueira, J.F.; Rôças, I.N. Clinical implications and microbiology of bacterial persistence after treatment procedures. J. Endod. 2008, 34, 1291-1301. [CrossRef]

2. Narayanan, L.L.; Vaishnavi, C. Endodontic microbiology. J. Conserv. Dent. 2010, 13, 233-239. [CrossRef]

3. Nair, P.N.R. On the causes of persistent apical periodontitis: A review. Int. Endod. J. 2006, 39, 249-281. [CrossRef] [PubMed]

4. Sundqvist, G. Ecology of the root canal flora. J. Endod. 1992, 18, 427-430. [CrossRef]

5. Abouelenien, S.S.; Ibrahim, S.M.; Shaker, O.G.; Ahmed, G.M. Evaluation of postoperative pain in infected root canals after using double antibiotic paste versus calcium hydroxide as intra-canal medication: A randomized controlled trial. F1000Research 2018, 7 , 1768. [CrossRef]

6. $\quad$ Arruda, M.E.F.; Neves, M.A.S.; Diogenes, A.; Mdala, I.; Guilherme, B.P.S.; Siqueira, J.F.; Rôças, I.N. Infection control in teeth with apical periodontitis using a triple antibiotic solution or calcium hydroxide with chlorhexidine: A Randomized Clinical Trial. $J$. Endod. 2018, 44, 1474-1479. [CrossRef] [PubMed] 
7. Ghatole, K.; Gowdra, R.H.G.; Azher, S.; Sabharwal, S.; Singh, V.T.; Sundararajan, B.V. Enhancing the antibacterial activity of the gold standard intracanal medicament with incorporation of silver zeolite: An in vitro study. J. Int. Soc. Prev. Community Dent. 2016, 6, 75-79. [CrossRef] [PubMed]

8. Mohammadi, Z.; Dummer, P.M.H. Properties and applications of calcium hydroxide in endodontics and dental traumatology. Int Endod. J. 2011, 44, 697-730. [CrossRef] [PubMed]

9. Sukawat, C.; Srisuwan, T. A comparison of the antimicrobial efficacy of three calcium hydroxide formulations on human dentin infected with Enterococcus faecalis. J. Endod. 2002, 28, 102-104. [CrossRef]

10. Siqueira, J.F.; Lopes, H.P. Mechanisms of antimicrobial activity of calcium hydroxide: A critical review. Int. Endod. J. 1999, 32, 361-369. [CrossRef] [PubMed]

11. Kumar, G.; Tewari, S.; Tagg, J.; Chikindas, M.L.; Popov, I.V.; Tiwari, S.K. Can Probiotics Emerge as Effective Therapeutic Agents in Apical Periodontitis? A Review. Probiotics Antimicrob. Proteins 2021, 13, 299-314. [CrossRef]

12. Kim, D.; Kim, E. Antimicrobial effect of calcium hydroxide as an intracanal medicament in root canal treatment: A literature review-Part I. In vitro studies. Restor. Dent. Endod. 2014, 39, 241-252. [CrossRef] [PubMed]

13. Basrani, B.; Tjäderhane, L.; Santos, J.M.; Pascon, E.; Grad, H.; Lawrence, H.P.; Friedman, S. Efficacy of chlorhexidine- and calcium hydroxide-containing medicaments against Enterococcus faecalis in vitro. Oral Surg. Oral Med. Oral Pathol. Oral Radiol. Endod. 2003, 96, 618-624. [CrossRef]

14. Punathil, S.; Moyin, S.; Bhat, S.S.; Hedge, S.; Pai, A.; James, J. Comparison of Antibacterial Effect of Calcium Hydroxide Combined with Chlorhexidine and Povidone-Iodine Against Enterococcus faecalis in Dentinal Tubules of Human Incisors: An In Vitro Comparative Study. J. Pharm. Bioallied Sci. 2020, 12 (Suppl. S1), S448-S452. [CrossRef] [PubMed]

15. Evans, M.D.; Baumgartner, J.C.; Khemaleelakul, S.; Xia, T. Efficacy of calcium hydroxide: Chlorhexidine paste as an intracanal medication in bovine dentin. J. Endod. 2003, 29, 338-339. [CrossRef]

16. Pereira, T.C.; Vasconcelos, L.R.D.S.M.; Graeff, M.S.Z.; Ribeiro, M.C.M.; Duarte, M.A.H.; de Andrade, F.B. Intratubular decontamination ability and physicochemical properties of calcium hydroxide pastes. Clin. Oral Investig. 2019, 23, 1253-1262. [CrossRef] [PubMed]

17. Gomes, B.P.F.D.A.; Vianna, M.E.; Sena, N.T.; Zaia, A.A.; Ferraz, C.C.R.; de Souza Filho, F.J. In vitro evaluation of the antimicrobial activity of calcium hydroxide combined with chlorhexidine gel used as intracanal medicament. Oral Surg. Oral Med. Oral Pathol. Oral Radiol. Endod. 2006, 102, 544-550.

18. Ercan, E.; Dalli, M.; Dülgergil, C.T. In vitro assessment of the effectiveness of chlorhexidine gel and calcium hydroxide paste with chlorhexidine against Enterococcus faecalis and Candida albicans. Oral Surg. Oral Med. Oral Pathol. Oral Radiol. Endod. 2006, 102, e27-e31. [CrossRef]

19. Delgado, R.J.R.; Gasparoto, T.H.; Sipert, C.R.; Pinheiro, C.R.; Moraes, I.G.; Garcia, R.B.; Bramante, C.M.; Campanelli, A.P.; Bernardineli, N. Antimicrobial effects of calcium hydroxide and chlorhexidine on Enterococcus faecalis. J. Endod. 2010, 36, 1389-1393. [CrossRef]

20. Prabhakar, A.R.; Hadakar, S.G.; Raju, O.S. Comparative evaluation of $\mathrm{pH}$ and antibacterial effect of various calcium hydroxide combinations on E. faecalis and its effect on root strength: An in vitro study. Contemp. Clin. Dent. 2012, 3, 42-47. [CrossRef]

21. Almyroudi, A.; Mackenzie, D.; McHugh, S.; Saunders, W.P. The effectiveness of various disinfectants used as endodontic intracanal medications: An in vitro study. J. Endod. 2002, 28, 163-167. [CrossRef]

22. Schäfer, E.; Bössmann, K. Antimicrobial efficacy of chlorhexidine and two calcium hydroxide formulations against Enterococcus faecalis. J. Endod. 2005, 31, 53-56. [CrossRef] [PubMed]

23. Lynne, R.E.; Liewehr, F.R.; West, L.A.; Patton, W.R.; Buxton, T.B.; McPherson, J.C. In vitro antimicrobial activity of various medication preparations on E. faecalis in root canal dentin. J. Endod. 2003, 29, 187-190.

24. Afkhami, F.; Pourhashemi, S.J.; Sadegh, M.; Salehi, Y.; Fard, M.J.K. Antibiofilm efficacy of silver nanoparticles as a vehicle for calcium hydroxide medicament against Enterococcus faecalis. J. Dent. 2015, 43, 1573-1579. [CrossRef]

25. Charannya, S.; Duraivel, D.; Padminee, K.; Poorni, S.; Nishanthine, C.; Srinivasan, M.R. Comparative Evaluation of Antimicrobial Efficacy of Silver Nanoparticles and 2\% Chlorhexidine Gluconate When Used Alone and in Combination Assessed Using Agar Diffusion Method: An In vitro Study. Contemp. Clin. Dent. 2018, 9 (Suppl. S2), S204-S209. [CrossRef]

26. Ahrari, F.; Eslami, N.; Rajabi, O.; Ghazvini, K.; Barati, S. The antimicrobial sensitivity of Streptococcus mutans and Streptococcus sanguis to colloidal solutions of different nanoparticles applied as mouthwashes. Dent. Res. J. 2015, 12, 44-49.

27. Yousefshahi, H.; Aminsobhani, M.; Shokri, M.; Shahbazi, R. Anti-bacterial properties of calcium hydroxide in combination with silver, copper, zinc oxide or magnesium oxide. Eur. J. Transl. Myol. 2018, 28, 7545. [CrossRef] [PubMed]

28. Lemire, J.A.; Harrison, J.J.; Turner, R.J. Antimicrobial activity of metals: Mechanisms, molecular targets and applications. Nat. Rev. Microbiol. 2013, 11,371-384. [CrossRef]

29. Campoccia, D.; Ravaioli, S.; Vivani, R.; Donnadio, A.; Vischini, E.; Russo, A.; Visai, L.; Arciola, C.R.; Montanaro, L.; Nocchetti, M. Antibacterial Properties of a Novel Zirconium Phosphate-Glycinediphosphonate Loaded with Either Zinc or Silver. Materials 2019, 12, 3184. [CrossRef] [PubMed]

30. Samiei, M.; Torab, A.; Hosseini, O.; Abbasi, T.; Abdollahi, A.A.; Divband, B. Antibacterial Effect of Two Nano Zinc Oxide Gel Preparations Compared to Calcium Hydroxide and Chlorhexidine Mixture. Iran. Endod. J. 2018, 13, 305-311. [PubMed] 
31. Nunes, B.S.; Rosendo, R.A.; Filho, A.A.O.; Fook, M.V.L.; de Sousa, W.J.B.; Barbosa, R.C.; Pina, H.N.; da Silva Neto, J.E.; Amoah, S.K.S.; Fontana, S.E.; et al. Chitosan-Based Biomaterial, Calcium Hydroxide and Chlorhexidine for Potential Use as Intracanal Medication. Materials 2021, 14, 488. [CrossRef]

32. Revathi, T.; Thambidurai, S. Cytotoxic, antioxidant and antibacterial activities of copper oxide incorporated chitosan-neem seed biocomposites. Int. J. Biol. Macromol. 2019, 139, 867-878. [CrossRef] [PubMed]

33. Mogrovejo-Valdivia, A.; Rahmouni, O.; Tabary, N.; Maton, M.; Neut, C.; Martel, B.; Blanchemain, N. In vitro evaluation of drug release and antibacterial activity of a silver-loaded wound dressing coated with a multilayer system. Int. J. Pharm. 2019, 556, 301-310. [CrossRef]

34. Palza, H. Antimicrobial polymers with metal nanoparticles. Int. J. Mol. Sci. 2015, 16, 2099-2116. [CrossRef] [PubMed]

35. Ma, Q.; Song, J.; Zhang, S.; Wang, M.; Guo, Y.; Dong, C. Colorimetric detection of riboflavin by silver nanoparticles capped with $\beta$-cyclodextrin-grafted citrate. Colloids Surf. B Biointerfaces 2016, 148, 66-72. [CrossRef] [PubMed]

36. Carapeto, A.P.; Ferraria, A.M.; do Rego, A.M.B. Unraveling the reaction mechanism of silver ions reduction by chitosan from so far neglected spectroscopic features. Carbohydr. Polym. 2017, 174, 601-609. [CrossRef]

37. Bano, I.; Arshad, M.; Yasin, T.; Ghauri, M.A.; Younus, M. Chitosan: A potential biopolymer for wound management. Int. J. Biol. Macromol. 2017, 102, 380-383. [CrossRef] [PubMed]

38. Blanchemain, N.; Karrout, Y.; Tabary, N.; Bria, M.; Neut, C.; Hildebrand, H.F.; Siepmann, J.; Martel, B. Comparative study of vascular prostheses coated with polycyclodextrins for controlled ciprofloxacin release. Carbohydr. Polym. 2012, 90, 1695-1703. [CrossRef] [PubMed]

39. Flores, C.; Lopez, M.; Tabary, N.; Neut, C.; Chai, F.; Betbeder, D.; Herkt, C.; Cazaux, F.; Gaucher, V.; Martel, B.; et al. Preparation and characterization of novel chitosan and $\beta$-cyclodextrin polymer sponges for wound dressing applications. Carbohydr. Polym. 2017, 173, 535-546. [CrossRef] [PubMed]

40. Ouerghemmi, S.; Degoutin, S.; Tabary, N.; Cazaux, F.; Maton, M.; Gaucher, V.; Janus, L.; Neut, C.; Chai, F.; Martel, B.; et al. Triclosan loaded electrospun nanofibers based on a cyclodextrin polymer and chitosan polyelectrolyte complex. Int. J. Pharm. 2016, 513, 483-495. [CrossRef] [PubMed]

41. Garcia-Fernandez, M.J.; Maton, M.; Benzine, Y.; Tabary, N.; Baptiste, E.J.; Gargouri, M.; Bria, M.; Blanchemain, N.; Karoutt, Y. Ciprofloxacin loaded vascular prostheses functionalized with poly-methylbeta- cyclodextrin: The importance of in vitro release conditions. J. Drug Deliv. Sci. Technol. 2019, 53, 101166. [CrossRef]

42. Vermet, G.; Degoutin, S.; Chai, F.; Maton, M.; Flores, C.; Neut, C.; Danjou, P.E.; Blanchemain, N.; Martel, B. Cyclodextrin modified PLLA parietal reinforcement implant with prolonged antibacterial activity. Acta Biomater. 2017, 53, 222-232. [CrossRef] [PubMed]

43. Vermet, G.; Degoutin, S.; Chai, F.; Maton, M.; Bria, M.; Danel, C.; Hildebrand, H.F.; Blanchemain, N.; Martel, B. Visceral mesh modified with cyclodextrin for the local sustained delivery of ropivacaine. Int. J. Pharm. 2014, 476, 149-159. [CrossRef] [PubMed]

44. Jansook, P.; Ogawa, N.; Loftsson, T. Cyclodextrins: Structure, physicochemical properties and pharmaceutical applications. Int. J. Pharm. 2018, 535, 272-284. [CrossRef]

45. Tomson, R.M.E.; Polycarpou, N.; Tomson, P.L. Contemporary obturation of the root canal system. Br. Dent. J. 2014, 216, 315-322. [CrossRef]

46. Komabayashi, T.; Colmenar, D.; Cvach, N.; Bhat, A.; Primus, C.; Imai, Y. Comprehensive review of current endodontic sealers. Dent. Mater. J. 2020, 39, 703-720. [CrossRef] [PubMed]

47. Kreth, J.; Kim, D.; Nguyen, M.; Hsiao, G.; Mito, R.; Kang, M.K.; Chugal, N.; Chi, W. The Antimicrobial Effect of Silver Ion Impregnation into Endodontic Sealer against Streptococcus mutans. Open Dent. J. 2008, 2, 18-23.

48. Noronha, V.T.; Paula, A.J.; Durán, G.; Galembeck, A.; Cogo-Müller, K.; Franz-Montan, M.; Duran, N. Silver nanoparticles in dentistry. Dent. Mater. 2017, 33, 1110-1126. [CrossRef]

49. Fujioka-Kobayashi, M.; Schaller, B.; Pikos, M.A.; Sculean, A.; Miron, R.J. Cytotoxicity and Gene Expression Changes of a Novel Homeopathic Antiseptic Oral Rinse in Comparison to Chlorhexidine in Gingival Fibroblasts. Materials 2020, 13, E3190. [CrossRef]

50. Vestergaard, M.; Skive, B.; Domraceva, I.; Ingmer, H.; Franzyk, H. Peptide/ $\beta$-Peptoid Hybrids with Activity against VancomycinResistant Enterococci: Influence of Hydrophobicity and Structural Features on Antibacterial and Hemolytic Properties. Int. J. Mol. Sci. 2021, 22, 5617. [CrossRef]

51. Zhang, S.; Tang, H.; Wang, Y.; Nie, B.; Yang, H.; Yuan, W.; Qu, X.; Yue, B. Antibacterial and antibiofilm effects of flufenamic acid against methicillin-resistant Staphylococcus aureus. Pharmacol. Res. 2020, 160, 105067. [CrossRef]

52. Tavares, T.D.; Antunes, J.C.; Padrão, J.; Ribeiro, A.I.; Zille, A.; Amorim, M.T.P.; Farreira, F.; Felgueiras, H.P. Activity of specialized biomolecules against Gram-positive and Gram-negative bacteria. Antibiotics 2020, 9, 314. [CrossRef]

53. Aghatabay, N.M.; Neshat, A.; Karabiyik, T.; Somer, M.; Haciu, D.; Dülger, B. Synthesis, characterization and antimicrobial activity of Fe(II), Zn(II), Cd(II) and Hg(II) complexes with 2,6-bis(benzimidazol-2-yl) pyridine ligand. Eur. J. Med. Chem. 2007, 42, 205-213. [CrossRef] [PubMed]

54. Martínez, A.; Apip, C.; Meléndrez, M.F.; Domínguez, M.; Sánchez-Sanhueza, G.; Marzialetti, T.; Catalán, A. Dual antifungal activity against Candida albicans of copper metallic nanostructures and hierarchical copper oxide marigold-like nanostructures grown in situ in the culture medium. J. Appl. Microbiol. 2021, 130, 1883-1892. [CrossRef]

55. Meto, A.; Colombari, B.; Sala, A.; Pericolini, E.; Meto, A.; Peppoloni, S.; Blasi, E. Antimicrobial and antibiofilm efficacy of a copper/calcium hydroxide-based endodontic paste against Staphylococcus aureus, Pseudomonas aeruginosa and Candida albicans. Dent. Mater. J. 2019, 38, 591-603. [CrossRef] 
56. Nozari, A.; Karimkhani, A.; Motamedifar, M.; Arasteh, P. The antimicrobial effects of zinc oxide-calcium hydroxide mixture fillers: Determining the ideal mixture ratio. Iran. J. Microbiol. 2019, 11, 239-245. [CrossRef] [PubMed]

57. Almoudi, M.M.; Hussein, A.S.; Abu Hassan, M.I.; Zain, N.M. A systematic review on antibacterial activity of zinc against Streptococcus mutans. Saudi Dent. J. 2018, 30, 283-291. [CrossRef] [PubMed]

58. Bradshaw, D.J.; Marsh, P.D.; Watson, G.K.; Cummins, D. The effects of triclosan and zinc citrate, alone and in combination, on a community of oral bacteria grown in vitro. J. Dent. Res. 1993, 72, 25-30. [CrossRef] [PubMed]

59. Cui, J.; Sun, Q.; Duan, M.; Liu, D.; Fan, W. Establishment and characterization of silver-resistant Enterococcus faecalis. Folia Microbiol. 2020, 65, 721-733. [CrossRef]

60. Kulatunga, D.; Dananjaya, S.; Godahewa, G.I.; Lee, J.; De Zoysa, M. Chitosan silver nanocomposite (CAgNC) as an antifungal agent against Candida albicans. Med. Mycol. 2017, 55, 213-222. [CrossRef]

61. Freire, P.L.L.; Albuquerque, A.J.R.; Farias, I.A.P.; da Silva, T.G.; Aguiar, J.S.; Galembeck, A.; Flores, M.A.P.; Sampaio, F.C.; Stamford, T.C.M.; Rosenblatt, A. Antimicrobial and cytotoxicity evaluation of colloidal chitosan-silver nanoparticles-fluoride nanocomposites. Int. J. Biol. Macromol. 2016, 93, 896-903. [CrossRef]

62. Sy, K.; Flamme, J.; Maquet, H.; Chai, F.; Neut, C.; Siepmann, F.; Agossa, K. Antimicrobial effect and physical properties of an injectable 'active oxygen' gel for the treatment of periodontitis. Am. J. Dent. 2020, 33, 305-309.

63. Saatchi, M.; Shokraneh, A.; Navaei, H.; Maracy, M.R.; Shojaei, H. Antibacterial effect of calcium hydroxide combined with chlorhexidine on Enterococcus faecalis: A systematic review and meta-analysis. J. Appl. Oral Sci. 2014, 22, 356-365. [CrossRef]

64. Bonev, B.; Hooper, J.; Parisot, J. Principles of assessing bacterial susceptibility to antibiotics using the agar diffusion method. J. Antimicrob. Chemother. 2008, 61, 1295-1301. [CrossRef]

65. Ingle, J.I.; Bakland, L.K.; Baumgartner, J.C. Endodontics, 6th ed.; BC Decker: Bloomington, IN, USA, 2008 ; p. 996.

66. Siqueira, J.F.; de Uzeda, M. Intracanal medicaments: Evaluation of the antibacterial effects of chlorhexidine, metronidazole, and calcium hydroxide associated with three vehicles. J. Endod. 1997, 23, 167-169. [CrossRef]

67. Tülü, G.; Kaya, B.Ü.; Çetin, E.S.; Köle, M. Antibacterial effect of silver nanoparticles mixed with calcium hydroxide or chlorhexidine on multispecies biofilms. Odontology 2021, 109, 802-811. [CrossRef] [PubMed]

68. Pratsinis, A.; Hervella, P.; Leroux, J.-C.; Pratsinis, S.E.; Sotiriou, G.A. Toxicity of silver nanoparticles in macrophages. Small 2013, 9, 2576-2584. [CrossRef]

69. Agnihotri, S.; Mukherji, S.; Mukherji, S. Size-controlled silver nanoparticles synthesized over the range 5-100 nm using the same protocol and their antibacterial efficacy. RSC Adv. 2014, 4, 3974-3983. [CrossRef]

70. Rai, M.; Yadav, A.; Gade, A. Silver nanoparticles as a new generation of antimicrobials. Biotechnol. Adv. 2009, 27, 76-83. [CrossRef]

71. Morones, J.R.; Elechiguerra, J.L.; Camacho, A.; Holt, K.; Kouri, J.B.; Ramírez, J.T.; Yacaman, M.J. The bactericidal effect of silver nanoparticles. Nanotechnology 2005, 16, 2346-2353. [CrossRef]

72. Chatterjee, T.; Chatterjee, B.K.; Majumdar, D.; Chakrabarti, P. Antibacterial effect of silver nanoparticles and the modeling of bacterial growth kinetics using a modified Gompertz model. Biochim. Biophys. Acta 2015, 1850, 299-306. [CrossRef]

73. Waltimo, T.M.; Sirén, E.K.; Orstavik, D.; Haapasalo, M.P. Susceptibility of oral Candida species to calcium hydroxide in vitro. Int. Endod. J. 1999, 32, 94-98. [CrossRef] [PubMed]

74. Weckwerth, P.H.; Carnietto, C.; Weckwerth, A.C.V.B.; Duarte, M.A.H.; Kuga, M.C.; Vivan, R.R. In vitro susceptibility of oral Candida albicans strains to different $\mathrm{pH}$ levels and calcium hydroxide saturated aqueous solution. Braz. Dent. J. 2012, 23, 192-198. [CrossRef]

75. Sen, B.H.; Safavi, K.E.; Spångberg, L.S. Growth patterns of Candida albicans in relation to radicular dentin. Oral Surg. Oral Med. Oral Pathol. Oral Radiol. Endod. 1997, 84, 68-73. [CrossRef]

76. Haapasalo, H.K.; Sirén, E.K.; Waltimo, T.M.; Ørstavik, D.; Haapasalo, M.P. Inactivation of local root canal medicaments by dentine: An in vitro study. Int. Endod. J. 2000, 33, 126-131. [CrossRef] [PubMed]

77. Gutmann, J.L. Grossman's Endodontic Practice-13th Edition. J. Conserv. Dent. 2016, 19, 494. [CrossRef]

78. Calt, S.; Serper, A. Dentinal tubule penetration of root canal sealers after root canal dressing with calcium hydroxide. J. Endod. 1999, 25, 431-433. [CrossRef]

79. Chang, S.W.; Lee, Y.-K.; Zhu, Q.; Shon, W.J.; Lee, W.C.; Kum, K.Y.; Baek, S.H.; Lee, I.B.; Lim, B.-S.; Bae, K.S. Comparison of the rheological properties of four root canal sealers. Int. J. Oral Sci. 2015, 7, 56-61. [CrossRef] [PubMed]

80. Marin-Bauza, G.A.; Rached-Junior, F.J.A.; Souza-Gabriel, A.E.; Sousa-Neto, M.D.; Miranda, C.E.S.; Silva-Sousa, Y.T.C. Physicochemical properties of methacrylate resin-based root canal sealers. J. Endod. 2010, 36, 1531-1536. [CrossRef]

81. Siqueira, J.F.; Favieri, A.; Gahyva, S.M.; Moraes, S.R.; Lima, K.C.; Lopes, H.P. Antimicrobial activity and flow rate of newer and established root canal sealers. J. Endod. 2000, 26, 274-277. [CrossRef]

82. De Freitas, J.V.; Ebert, J.; Mazzi-Chaves, J.F.; de Sousa-Neto, M.D.; Lohbauer, U.; Baratto-Filho, F. Do Contaminating Substances Influence the Rheological Properties of Root Canal Sealers? J. Endod. 2020, 46, 258-263. [CrossRef] [PubMed]

83. Kaplan, A.E.; Ormaechea, M.F.; Picca, M.; Canzobre, M.C.; Ubios, A.M. Rheological properties and biocompatibility of endodontic sealers. Int. Endod. J. 2003, 36, 527-532. [CrossRef] [PubMed]

84. Agossa, K.; Lizambard, M.; Rongthong, T.; Delcourt-Debruyne, E.; Siepmann, J.; Siepmann, F. Physical key properties of antibioticfree, PLGA/HPMC-based in-situ forming implants for local periodontitis treatment. Int. J. Pharm. 2017, 521, 282-293. [CrossRef] [PubMed] 
85. Li, M.; Yang, Y.; Lin, C.; Zhang, Q.; Gong, L.; Wang, Y.; Zhang, X. Antibacterial Properties of Small-Size Peptide Derived from Penetratin against Oral Streptococci. Materials 2021, 14, 2730. [CrossRef]

86. Abedini, A.; Roumy, V.; Mahieux, S.; Gohari, A.; Farimani, M.M.; Rivière, C.; Samaillie, J.; Sahpaz, S.; Bailleul, F.; Neut, C.; et al. Antimicrobial activity of selected Iranian medicinal plants against a broad spectrum of pathogenic and drug multiresistant micro-organisms. Lett. Appl. Microbiol. 2014, 59, 412-421. [CrossRef] [PubMed]

87. Lizambard, M.; Menu, T.; Fossart, M.; Bassand, C.; Agossa, K.; Huck, O.; Neut, C.; Siepmann, F. In-situ forming implants for the treatment of periodontal diseases: Simultaneous controlled release of an antiseptic and an anti-inflammatory drug. Int. J. Pharm. 2019, 572, 118833. [CrossRef]

88. Winkler, B.; Margerison, J.K. Mechanical properties of the bovine claw horn during lactation. J. Dairy Sci. 2012, 95, 1714-1728. [CrossRef] [PubMed]

89. Palomino-Durand, C.; Lopez, M.; Cazaux, F.; Martel, B.; Blanchemain, N.; Chai, F. Influence of the Soluble-Insoluble Ratios of Cyclodextrins Polymers on the Viscoelastic Properties of Injectable Chitosan-Based Hydrogels for Biomedical Application. Polymers 2019, 11, 214. [CrossRef] 